\title{
The effect of low-temperature plasma discharge on mycotoxin content in barley and malt
}

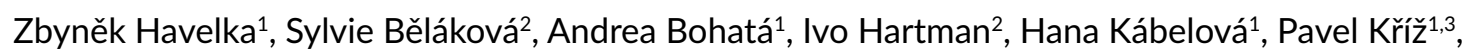 \\ Karolína Benešová ${ }^{*}$, Miroslav Dienstbier ${ }^{2}$, Petr Bartoš ${ }^{1,3}$ and Petr Špatenka ${ }^{1,4}$ \\ 1 Faculty of Agriculture, University of South Bohemia in České \\ Budějovice, Studentská 1668, 37005 České Budějovice, \\ 4 Faculty of Mechanical Engineering, Czech Technical University \\ Czech Republic. \\ 2 Research Institute of Brewing and Malting, Mostecká 7 , \\ 61400 Brno, Czech Republic.
}

3 Faculty of Education, University of South Bohemia in České Budějovice, Jeronýmova 10, 37115 České Budějovice, Czech Republic.

\begin{abstract}
Contamination of malting barley by mycotoxins affects their presence in malt and in the resulting product - beer. Therefore, methods are being developed to eliminate or reduce their concentration. This work deals with the possibility of elimination of common occurring mycotoxins deoxynivalenol (DON) and its plant metabolite deoxynivalenol-3-glucoside (D3G) from malting barley and malt using low-temperature plasma discharge of Gliding Arc type. Samples of harvested barley were plasma-treated and analyzed for the presence of mycotoxins. Only low levels of DON and D3G were detected (maximum values were $48.2 \mu \mathrm{g} / \mathrm{kg}$ and $30.2 \mu \mathrm{g} / \mathrm{kg}$ for DON and D3G, respectively). After treatment of plasma discharge, mycotoxin levels decreased to levels near the limit of quantification. The results indicate that the low-temperature plasma discharge of Gliding Arc type may contribute to the reduction of mycotoxin content in harvested barley grains. Due to low concentrations, the effect of plasma treatment in malt was not confirmed.
\end{abstract}

Keywords: plasma treatment, grains, detoxification, toxic metabolites, biological protection

\section{Introduction}

Mycotoxins are toxic and thermostable secondary metabolites produced by specific fungi occurring naturally in most agricultural crops; therefore, they are also found in the whole nutrition chain (Bennet, 1987). The most significant toxigenic fungi include Fusarium, Alternaria, Stemphylium, Cladosporium, Aspergillus, Penicillium, and Rhizopus species (Medina et al., 2015). Mycotoxins can accumulate in food commodities on fields, after harvest and during storage. Due to various toxic effects of mycotoxins and their temperature resistance, mycotoxins pose a potential risk to human and animal health. The most serious effects include hepatotoxicity and neurotoxicity (Eaton et al., 2010) and late toxic effects such as carcinogenicity, immunotoxicity and developmental toxicity. Foods can also be contaminated with more than one mycotoxin, which may increase these health risks (Spejiers and Speijers, 2004). Crop production creates a wide range of complex relationships and interactions between the plant, microscopic fungi, insects and the manner of plant treatment. These interactions then affect production and mycotoxin content in food raw materials. Appropriate agro-technical measures are employed that contribute to production of raw materials for food with lowered mycotoxin content (Velíšek and Hajšlová, 2009). Deoxynivalenol (DON) belongs to the most studied and investigated mycotoxins. Its important producer is Fusar- 
ium graminearum, followed by F. culmorum with lower temperature requirements (the optimum is $21^{\circ} \mathrm{C}$ ). The occurrence of DON in cereals varies strongly from one year to another, depending mainly on the weather conditions in the locality, pre-crop and the variety resistance. In some years, nearly $100 \%$ of the studied samples exhibit the presence of this mycotoxin (Velíšek and Hajšlová, 2009; Běláková et al., 2014); for this reason, DON is considered to be the main food contaminant. It is an indicator (marker) of possible contamination with other trichothecenic mycotoxins. DON frequently co-occurs with other mycotoxins in cereals, often accompanied by isomers of acetylated 3- and 15-acetyldeoxynivalenol (ADONs) as well as nivalenol (NIV) (Pestka, 2007).

Mycotoxins are partially metabolized and produce conjugated forms with saccharides. Plants attacked by toxigenic fibrous fungi respond with their natural defense mechanisms. During chemical reactions occurring in the plant organs, tissues and organelles (oxidation, reduction, hydrolysis, methylation, glucosidation), toxins with active functional groups are converted into derivatives or conjugates by enzymes. Their harmfulness for plants is minimal and therefore, they can be stored in vacuoles (Berthiller et al., 2007; Hajšlová, 2008). The best investigated trichothecene conjugate, deoxynivalenol-3- $\beta$-D-glucopyranoside (D3G), is present in wheat in an amount corresponding to up to $30 \%$ of free DON molar concentration. Relatively high concentrations of D3G have been found in malt, beer and other fermented cereal products, with the molar DON to D3G ratio in some samples $\geq 1$ (Velíšek and Hajšlová, 2009). At present, it is not possible to say whether D3G, as a detoxification plant product, exhibits acute toxicity or whether it breaks down again to DON in the body (Berthiller et al., 2007; Berthiller et al., 2013). Berthiller et al., 2011, however, reported the resistance of D3G to hydrochloric acid, this implies that it is not hydrolyzed in the mammalian stomach and thus is not cleaved back to DON. Other studies have shown partial cleavage of D3G by intestinal bacteria to DON (Berthiller et al., 2011).

Mycotoxins are resistant to most forms of food and feed processing. To avoid adverse health impacts and economic losses, intensive efforts have been currently made to reduce mycotoxin concentrations in raw materials and processed foods, both in pre-harvest stages and post-harvest processing (Patriarca and Pinto, 2017). The methods applied for the reduction of mycotoxin contamination include, in particular, the physical methods - mainly manual or automatic sorting of harvested commodities, grinding, soaking and further processing of cereals. In addition, chemical methods, oxidizing or reducing agents, enzymatic or microbial decontamination or active sorbent (binder) are applied (Karlovsky et al.,
2016). Biological degradation of mycotoxins, using microorganisms, fungi, bacteria and specific enzymes which are capable of converting mycotoxins with different efficiency to non or less toxic products have been described (Ji et al., 2016). Further possibilities include irradiation, microwave treatment or plasma discharge (Karlovsky et al., 2016). In food industry, the application of various types of plasma discharge currently represents a great potential for the reduction of microbial, bacterial (Moreau et al., 2005), fungal (Avramidis et al., 2010) and mycotoxin contamination. The last two mentioned authors used a Gliding Arc plasma discharge in their work.

The aim of our presented study was to monitor the effects of various types of barley seed treatments (chemical and biological dressing, low-temperature plasma discharge or their combination) and in addition, to find effects of the low-temperature Gliding Arc plasma discharge on the possible reduction of mycotoxin contamination of malting barley, harvested grain and malt produced from it.

\section{Materials and methods}

\subsection{Field trial}

The pilot experiment was established in Czech Republic, South Bohemia region on the experimental field of Zkušební stanice Kluky spol. s r.o. (Experimental Station Kluky).

The malting barley variety Francin was sown. The certified seed of spring barley was obtained from Selgen a.s. The average thousand grain weight (TGW) was $39.58 \mathrm{~g}$.

Before sowing, the seed was biologically and physically treated using fungicide $\left(\right.$ Raxil $^{\circledR}$ Star, fluopyram $1,72 \%$, prothioconazole $8,62 \%$, tebuconazole 5,17\%), Gliding Arc discharge plasma, mycoparasitic fungus Trichoderma virens or entomopathogenic fungus $\mathrm{Me}$ tarhizium anisopliae and a combination of dressing and plasma discharge.

The experiment in the Kluky u Písku was laid down on 24 March 2015 using a sowing machine of a Hege type. Harvest was carried out on 27 July 2015. The plot for the experiment was prepared in autumn 2014 according to the method optimal for malting barley growing in the given locality: $15 \% \mathrm{~N}, 15 \% \mathrm{~K}_{2} \mathrm{O}, 15 \% \mathrm{P}_{2} \mathrm{O}_{5}$ in autumn 2014. Within the experiment seven variants in four replications were sown (Figure 3). The area of each plot was $10 \mathrm{~m}^{2}$, i.e. $8 \times 1.25 \mathrm{~m}$. Experimental fields were established randomly.

\subsection{Treatment with beneficial filamentous fungal species} The seed was also treated with mycoparazitic Trichoderma virens and entomopathotogenic Metarhizium anisopli$a e$. Both fungal species are purposely used in biological plant protection worldwide. Trichoderma virens is a pol- 
yphagous fungal species capable of suppressing actively the cause of significant fungal diseases, including phytopathogenic Alternaria, Fusarium, Pythium, Sclerotinia and Rhizoctonia. The presence of Trichoderma virens in soil also positively affects plant rooting and development. Plants respond to the presence of this fungus by a socalled induced resistance, i.e. state of increased resistance to a spectrum of harmful organisms (López-Bucio et al., 2015). Metarhizium anisopliae species represents an effective prevention of damage to germinating and emerging plants caused by soil insect pests (Miranda-Hernández et al., 2016). Both beneficial fungi, T. virens and M. anisopliae, are preventively introduced into soil with seeds as they induce suppression of the fungal disease agents or soil pests in the sown crops. Within the experiments, seed was also prepared by dual treatment, i.e. the plasma-treated seed was subsequently dressed with beneficial fungal species.
Figure 1 Gliding Arc plasma nozzle

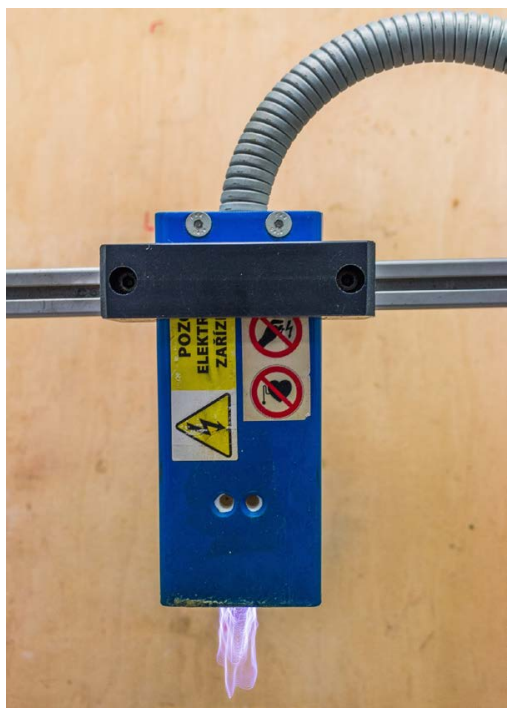

Figure 2 The transition between flame to filamentary mode of Gliding Arc discharge

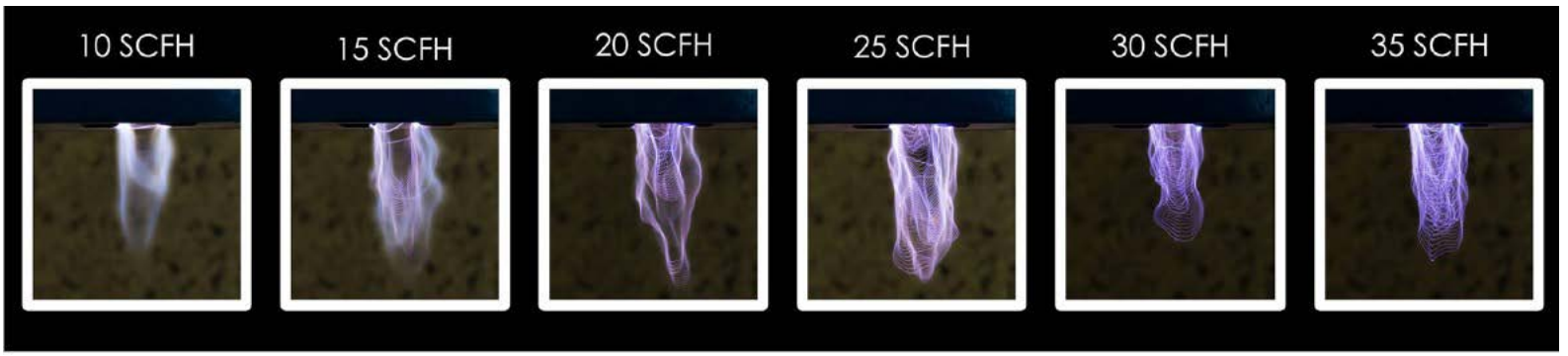

\subsection{Treatment with plasma discharge}

The experimental device we used was based on the effects of Gliding Arc plasma discharge generated under the atmospheric pressure. For a more detailed description see (Kříž et al., 2012). The discharge power was supplied by the RADAN high-voltage source GVN1k-2011 with a high voltage transformer $(10 \mathrm{kV})$ with a power input of $750 \mathrm{~W}$ operating at $50 \mathrm{~Hz}$. Compressed air was used as the working gas; the compressor pressure was set to about $600 \mathrm{kPa}$. The Omega FL-2008 rotameter built into the power supply allowed the flow rate to vary in the range from 10 to 100 SCFH (flow rate $1 \mathrm{Nm}^{3} \cdot \mathrm{h}^{-1}$ corresponds to $35.3 \mathrm{SCFH}$ ).

The plasma nozzle (Figure 1) was equipped with two divergent stainless-steel electrodes with the air gap of $2 \mathrm{~mm}$. The shape and thickness of the electrodes strongly affect the electric field in the vicinity of the electrodes (Bartoš et al., 2016) and thus indirectly the temperature of working gas flow indirectly. The electrodes used for the treatment were rectangular with one rounded corner with a diameter of $6 \mathrm{~mm}$. The plasma jet can work in two different regimes, flame or filamentary mode. It distinctly depended on working gas flow (see Figure 2) and also influenced the working gas temperature. For the experiments the working gas flow was adjusted to $30 \mathrm{SCFH}$ that corresponds to the end of a transient region toward to cold filamentary mode.

The distance between the sample and the plasma nozzle was set to $10 \mathrm{~cm}$, and $4 \mathrm{~cm}$ in the case of mycotoxin standards. The treated seed sample (150 g) was placed for four minutes in a stirrer. The stirrer consists of an open perforated tube body with a bottom blade mixer that rotates at $60 \mathrm{rpm}$ to stir the entire sample homogeneously.

\subsection{Samples}

In the field experiment (see subsection Field trial), seven barleys were grown in four replications. From these replications, one pooled sample was prepared. After harvest, the grain was dried on sieves to a standard dry matter of $14 \%$, the dried grain was stored in paper bags at room temperature, sorting was carried out on sieves and only healthy grains were tested regardless of their size. Of each barley sample, one half was plasma-treated. Subsequently, both plasma-treated and plasma untreated barleys were malted. In this way, a total of 28 barley and malt samples were prepared and analyzed (see Figure 3). 
Figure 3 Survey of all treatment variants of seeds, malting and analyses.

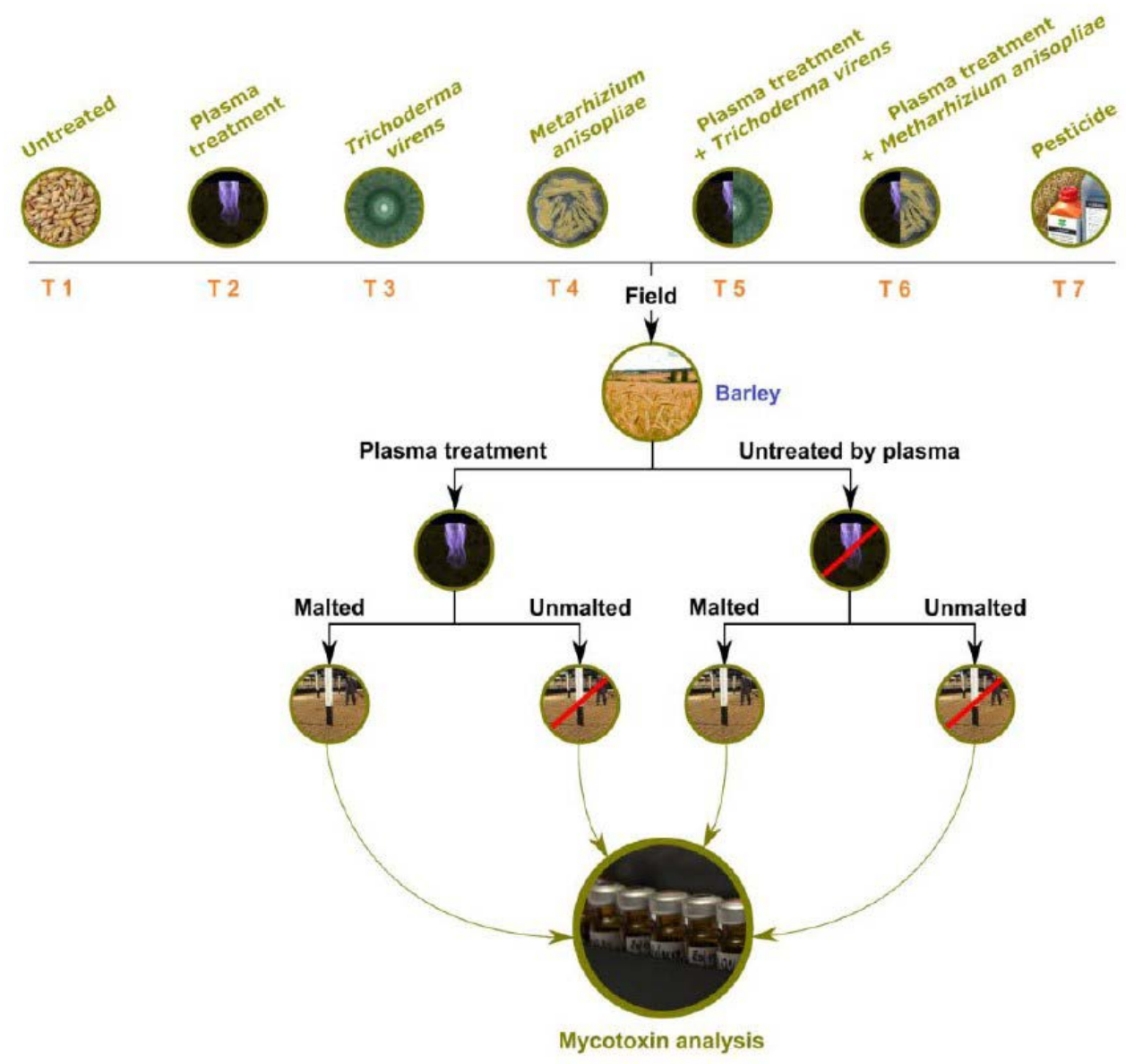

\subsection{Malting}

Micromalting was conducted in a laboratory micromalting plant of the company KVM (Czech Republic). The weight of each sample was $1 \mathrm{~kg}$. Steeping time was four hours the first day, and six hours the second day. On the third day water content in the steeped barley was adjusted to $45 \%$ by steeping or spraying. The water temperature and the air temperature during air resting were maintained at $14{ }^{\circ} \mathrm{C}$. After steeping, the barley was transferred to a combined box for germination and malt kilning. The grain germinated at the temperature of $14{ }^{\circ} \mathrm{C}$. The total germination and steeping time was 6 days. For kilning, a one-floor, electrically heated kiln was used, total kilning time was $1 \times 22$ hours, the prekilning temperature was $55^{\circ} \mathrm{C}$ for 12 hours and then it was increased by $4,2{ }^{\circ} \mathrm{C}$ each hour until it reached $80^{\circ} \mathrm{C}$. This temperature was then maintained for four hours.

\subsection{Determination of DON and D3G}

\section{Materials and reagents}

Standards of DON $(100 \mu \mathrm{g} / \mathrm{ml})$ and D3G (50 $\mu \mathrm{g} / \mathrm{ml})$, both solutions in acetonitrile, ammonium acetate, acetonitrile and methanol (HPLC and HPLC/MS grade) were obtained from Sigma-Aldrich, St. Luis, USA. Before use, the standard stock solution was prepared in mixture of methanol/ $\mathrm{H}_{2} \mathrm{O}(1 \mu \mathrm{g} / \mathrm{ml})$ and stored at $4{ }^{\circ} \mathrm{C}$ in the dark. Deionized water was prepared using the Milli-Q system (Merck-Millipore, Darmstadt, Germany).

Standard treatment by low-temperature plasma discharge A $10 \mu \mathrm{l}$ DON and D3G solution of $100 \mu \mathrm{g} / \mathrm{ml}$ in acetonitrile, i.e. 1,000 ng, was applied to the glass Petri dish. After evaporation of the solvent at room temperature, the dish was subjected to the plasma discharge under the same conditions as barley and malt samples for 0 and 4 minutes. The dish was then rinsed with $1 \mathrm{ml}$ of $\mathrm{MeOH}$ : $\mathrm{H}_{2} \mathrm{O}(50 / 50, v / v)$, the solution was transferred into a vial and analyzed by LC/MS. Each experiment was performed in three replicates.

\section{Sample preparation and extraction}

Barley or malt sample $25 \pm 0.1 \mathrm{~g}$ was milled, homogenized and supplemented with $200 \mathrm{ml}$ of water and shaken in a laboratory shaker for 50 minutes. The homogenized sample was centrifuged at $4000 \mathrm{rpm}$ for 10 minutes. The supernatant was filtered through a glass filter. After com- 
plete homogenization the sample was applied to the Donprep immunoaffinity column (R-Biopharm AG, Darmstadt, Germany) with a flow rate of 1-2 drops per second. The column was washed with $5 \mathrm{ml}$ of deionized water. Elution was repeated three times with $1.5 \mathrm{ml}$ of methanol (back flushing) at a flow rate lower or equal to one drop per second. The eluate was rotary evaporated to dryness under vacuum and redissolved in one $\mathrm{ml}$ of methanol/water $(50 / 50, v / v)$. The sample was filtered through a $0.22 \mu \mathrm{m}$ nylon microfilter prior to analysis.

Analysis of DON and D3G by HPLC-MS/MS, method validation HPLC (Finnigan Surveyor) coupled to ion trap LCQ Advantage (Thermo-Fisher, USA) with atmospheric pressure ionization was used for the identification and quantification of DON and D3G. The analysis used was performed according to the method described by Běláková et al., 2014. Method validation procedure was performed according to Běláková et al., 2014. Validation data is summarized in Table 1.

Table 1 Validation parameters of LC-MS/MS method.

\begin{tabular}{|c|c|c|c|c|}
\hline Analyte & $\begin{array}{c}\text { LOD } \\
(\mu \mathrm{g} / \mathrm{kg})\end{array}$ & $\begin{array}{c}\text { LOQ } \\
(\mu \mathrm{g} / \mathrm{kg})\end{array}$ & $\begin{array}{c}\text { RSD } \\
(\%)\end{array}$ & $\begin{array}{c}\text { Recovery } \\
(\%)\end{array}$ \\
\hline DON & 1,5 & 5 & 9,4 & 91,2 \\
\hline D3G & 1,5 & 5 & 9,9 & 87,7 \\
\hline
\end{tabular}

\section{Results and discussion}

\subsection{Plasma treated standards}

Low-temperature plasma treatment of pure mycotoxin standards leads to the degradation of DON and D3G by $96 \%$ (DON) or of $70 \%$ (D3G) after 4 minutes, respectively (see Figure 4). These results have been confirmed by other authors (Park et al., 2007; Bosch et al., 2017). Different degradation times are likely affected by the type of plasma used.

\subsection{Barleys}

The contamination of the harvested barley samples with DON in the described experiments was generally very low when compared with the values reported in previous years (e. g. Polišenská, et al., 2012; Běláková et al., 2014). The highest DON content in the original barley i.e. $48.19 \mu \mathrm{g} / \mathrm{kg}$ was found in the variant when seeds were treated with the fungi- cide (T7), the highest D3G content was $30.18 \mu \mathrm{g} / \mathrm{kg}$ (see Figure 5) in barley where seeds were untreated (T1).

These low values can be explained by a very dry and hot weather in the given year versus a long-term average (1961-1990). The conditions especially during the harvest period, were thus extremely adverse for the growth of fungi and mycotoxin production, namely during the harvest period. In the vegetation period of the field trial, the total precipitation sums in the South Bohemia region were $36-85 \%$ compared to the long-term average: the lowest value, $36 \%$ of standard, was measured in July, the highest, $118 \%$, in March. The temperature moved from 0.5 to $3.5^{\circ} \mathrm{C}$ above the long term average (Czech Hydrometeorological Institute, 2017), the highest value, $+3.5^{\circ} \mathrm{C}$ above the standard, was also measured in July when the studied samples were harvested.

According to previously published data (Malachová et al., 2010), chemical (fungicidal) treatment of barley stands may not affect mycotoxin occurrence significantly, on the contrary, an inappropriately chosen time, manner of chemical treatment or adverse weather conditions may lead to stress to the present fungi and higher mycotoxin production.

After treatment with low temperature plasma discharge, the content of DON decreased in all samples with the exception of the variant T4 where the DON content in the treated sample slightly increased - the level was at LOQ - $3.3 \mu \mathrm{g} / \mathrm{kg}$ (see Figure 5). The results of D3G showed similar trends. D3G content in barley, with the exception of variant T1 (30.18 $\mu \mathrm{g} / \mathrm{kg})$, moved between LOD and LOQ (to $3.59 \mu \mathrm{g} / \mathrm{kg}$ ), it also decreased after the treatment with
Figure 4 Time-dependent decay of pure DON and D3G standards exposed to low-temperature plasma discharge

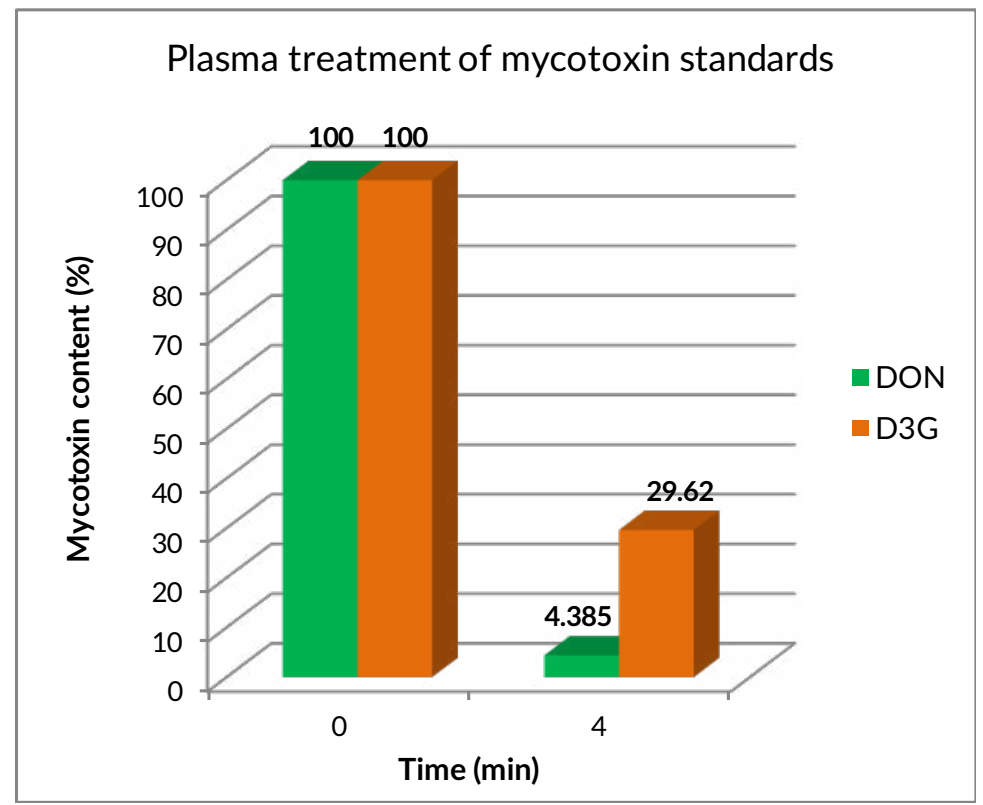


low-temperature discharge to levels around the LOD (to $1.57 \mu \mathrm{g} / \mathrm{kg}$ ) (see Figure 5). We can state that the treatment of harvested barley grain with low-temperature plasma discharge reduces DON and D3G contents.

Figure 5 DON and D3G content in barleys (NT = not treated) and plasma treated $(T)$ barleys.

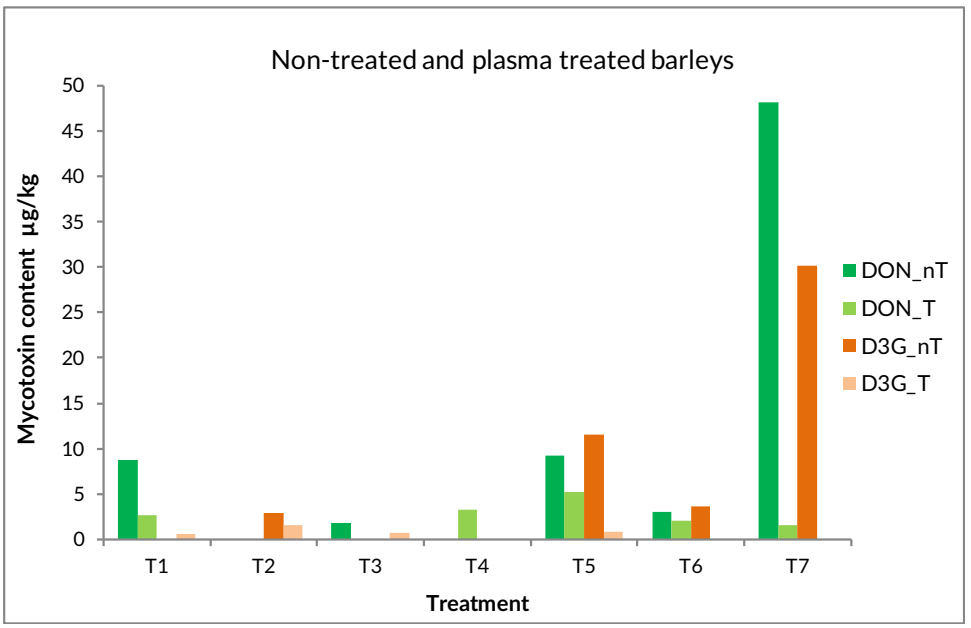

during germination DON could be converted to glycosylated D3G, and as a result of D3G cleavage during digestion back to DON, the increased D3G concentration can thus conceal toxicologically relevant DON content in the processed food and beer.

After malting of untreated barley, DON content mildly increased in all variants (the highest value $113.3 \mu \mathrm{g} / \mathrm{kg}, \mathrm{T} 6$ ) with the exception of T7. By contrast, DON content was below LOD in malts produced from treated barley except variant $\mathrm{T} 2$, T4 and T5 (see Figure 6a). The content of D3G varied in malts from plasma treated and plasma non-treated barley from below LOD to $85.2 \mu \mathrm{g} / \mathrm{kg}$ and the results did not show any trend (see Figure 6b). Considering the complexity of these relations, it cannot be unambiguously determine whether DON and D3G contents were affected by the previous manner of treatment.

We can conclude, that this uncertainty may be caused by the many factors and complicated relationships during malt-

\subsection{Malts}

During malting, mycotoxin concentrations both increase and decrease compared with the original material. Malting creates favorable conditions for the development of fungi and mycotoxins (Wolf-Hall, 2007). Mycotoxin concentration in various malting phases is affected by a number of factors, such as fungal strains, severity of the occurrence and fungus viability (injury, dormancy, death), mycelium or spores location, and synergic or antagonistic relations between the individual organisms. Contents of DON and other mycotoxins soluble in water decline due to their extraction into the steeping water, during germination the concentration usually increases (Malachová et al., 2010; Kostelanská et al., 2011). This can be linked with the activity of hydrolytic enzymes which very likely contribute to releasing of DON, D3G and other fusariotoxins from their bound forms to polysaccharides, such as starch. An alternative theory is mycotoxin production "de novo", this means a new mycotoxin production by fungal biomass that newly grows under favorable conditions (warm, humidity) during germination of barley (Malachová et al., 2010). During kilning of green malt, mycotoxin concentration can either decrease or increase compared to green malt and original barley (Malachová et al., 2010; Kostelanská et al., 2011). Increased temperature during kilning may lead to stress in some fungal species and thus stimulate an increased mycotoxin production (Wolf-Hall, 2007; Oliveira et al., 2012). Maul et al., 2012 concluded that ing and the effect of plasma treatment, when the D3G is under the same conditions degraded slowly than DON. Some authors proved, that the presence of matrix significantly reduced the degradation rates of some mycotoxins (Bosch et al., 2017). They also hypothesized, that the effect of the matrix on the degradation of other mycotoxins will be similar. In spite of protective matrix effects, suggesting that plasma-based methods are promising for mycotoxin degradation in the surface layers or in the complex matrices.

\section{Conclusion}

The research investigated the effect of low-temperature plasma discharge of Gliding Arc type on degradation of mycotoxins DON and D3G, barley grain contaminated by these mycotoxins and changes in concentration of monitored mycotoxins during malting. The use of plasma discharge has the effect of decreasing the concentration of pure mycotoxin standards and mycotoxins presented in harvested barley. Due to the low contamination of the harvested barley, the results of malted samples are unambiguous. No effect of previous seed treatment has been demonstrated. We can say that treatment of barley and possibly malt with plasma discharge has decontamination potential for the future use, but the results should be confirmed by further experiments on samples with measurable mycotoxin concentration. 
Figure 6 (a) DON and (b) D3G contents in malts produced from untreated and plasma treated barley. M_fNT = Malts from plasma not treated barley, $M_{-} f T$ = Malts from plasma treated barley.
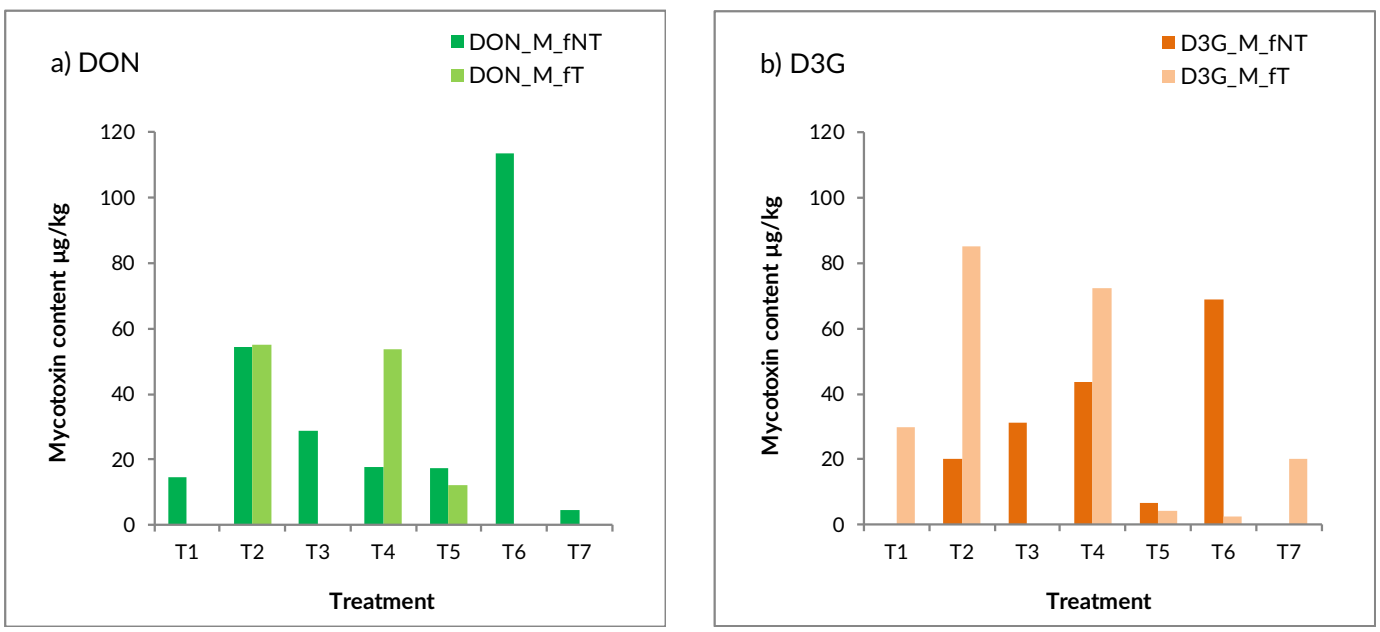

\section{Conflicts of Interest}

"The author(s) declare(s) that there is no conflict of interest regarding the publication of this paper."

\section{Funding Statement}

This work is based on the results achieved in the projects No TA04021252 - Development of equipment for the physical treatment of seeds and malt using low temperature plasma discharge and TA2000177 - Center for the Innovative Use and Strengthening of Competitiveness of Czech Brewery Raw Materials and Products. The authors thank to the Technology Agency of the Czech Republic for the financial support.

The work was also partially supported by the project of the MEYS of Czech Republic No. L01207 - Support of Sustainability of the Innovation Centre of Diagnostics and Applications of Materials at CTU FME in Prague.

\section{References}

Avramidis G., Stüwe B., Wascher R., Bellmann M., Wieneke S., von Tiedemann A., \& Wiöl W. (2010). Fungicidal effects of an atmospheric pressure gas discharge and degradation mechanisms. Surface and Coatings Technology, 205: 405-408. https://doi.org/10.1016/j.surfcoat.2010.08.141

Bartoš P., Ptáčník J., Kř́ž P., Špatenka P., Havelka Z., Olšan P., \& Veselý B. (2016): Distribution of electric field between electrodes in plasma jet: Computational study. Journal of Electrical Engineering. Timisoara, Romania: Politehnica, 16: 99-106. ISSN 1582-4594.

Běláková S., Benešová K., Čáslavský J., Svoboda Z., \& Mikulíková R. (2014): The occurrence of the selected fusarium mycotoxins in Czech malting barley. Food Control, 37: 93-98. https://doi.org/10.1016/j.foodcont.2013.09.033

Bennet J.W. (1987): Mycotoxins, mycotoxicoses, mycotoxicology and mycopatologia. Mycopatologia, 100: 3-5.

Berthiller F., Crews C., Dall'Asta Ch., De Saegar S., Haesaert G., Karlovsky P., Oswald I. P., Seefelder W., Spejiers G., \& Stroka J. (2013): Masked mycotoxins: A review. Molecular Nutrition \& Food Research, 57: 165-186. https://doi.org/10.1016/j.ijfoodmicro.2007.07.022

Berthiller F., Krska R., Domig K. J., Kneifel W., Juge N., Schuhmacher R., \& Adam G. (2011): Hydrolytic fate of deoxynivalenol-3-glucoside during digestion. Toxicology Letters, 206: 264-267. https://doi. org/10.1016/j.toxlet.2012.07.024

Berthiller F., Sulyok M., Krska R., \& Schuhmacher R. (2007): Chromatographic methods for the simultaneous determination of mycotoxins and their conjugates in cereals. International Journal of Food Microbiology, 119: 33-37. https://doi.org/10.1016/j.ijfoodmicro.2007.07.022

Bosch L., Pfohl K., Avramidis G., Wieneke S., Viöl W., \& Karlovsky, P. (2017). Plasma Based Degradation of Mycotoxins Produced by Fusarium, Aspergillus and Alternaria Species, Toxins, 9: 97-108. https://doi. org/10.3390/toxins9030097

Czech Hydrometeorological Institute, Retrieved from the website 2017-718, page http://portal.chmi.cz/historicka-data/pocasi/uzemni-teploty, http://portal.chmi.cz/historicka-data/pocasi/uzemni-srazky\#

Eaton D.L., Beima K.M., Bammler T.K., Riley R.T., \& Voss K.A. (2010): Hepatotoxic mycotoxins. Comprehensive Toxicology, 9: 527-569.

Hajšlová J. (2008): Mycotoxins and their conjugates in food raw materials and feed: trends, risks of dietary exposure, options of their fate prognosis at processing, cited 2018-11-2, page http://www.phytosanitary.org/projekty/2008/Projekt1.pdf, 2008 (in Czech)

Ji Ch., Fan Y., \& Zhao L. (2016): Review on biological degradation of mycotoxins. Animal Nutrition, 2: 127-133. https://doi.org/10.1016/j. aninu.2016.07.003

Karlovsky P., Suman M., Berthiller F., De Meester J., Eisenbrand G., Perrin I., Oswald I.P., Speijers G., Chiodini A., Recker T., \& Dussort P. (2016): Impact of food processing and detoxification treatments on mycotoxin contamination. Mycotoxin Research, 32: 179-205. https://doi. org/10.1007/s12550-016-0257-7

Kostelanská, M., Zachariášová, M., Džuman, Z., Hajšlová, J., Ehrenberegerová, J., Cerkal, R., Vaculová, K., Mikyška A., \& Psota, V.: (2011). Fusarium mycotoxins in spring barley and their occurrence within the technological chain barley-malt-beer. Kvasny Prumysl, 57: 219214. https://doi.org/10.18832/kp2011020

Kř́ž P., Haisan C., \& Špatenka P. (2012): Characterization of gliding arc device for industry applications, in Proceedings of the International Conference on Optimization of Electrical and Electronic Equipment (OPTIM), 1337-1340. 
López-Bucio J., Pelagio-Flores R., \& Herrera-Estrella A. (2015): Trichoderma as biostimulant: exploiting the multilevel properties of a plant beneficial fungus. Scientia Horticulturae, 196: 109-123. https://doi. org/10.1016/j.scienta.2015.08.043

Malachová, A., Hajšlová, J., Ehrenberegerová, J., Kostelanská, M., Zachariášová, M., Urbanová, J., Cerkal, R., Šafránková, I., Marková, J., Vaculová, K., \& Hrstková, J. (2010): Fusarium mycotoxins in spring barley and their transfer into malt. Kvasny Prumysl, 56: 131-137. https:// doi.org/10.18832/kp2010018

Maul, R., Müller, Ch., Rieß, S., Koch, M., Methner, F.J., \& Nehls, I. (2012): Germination induces the glucosylation of the Fusarium mycotoxin deoxynivalenol in various grains. Food Chemistry, 131: 274-279. https://doi.org/10.1016/j.foodchem.2011.08.077

Medina Á., Rodríguez A., \& Magan N. (2015). Climate change and mycotoxigenic fungi: impacts on mycotoxin production. Current Opinion in Food Science, 5: 99-104. https://doi.org/10.1016/j. cofs.2015.11.002

Miranda-Hernández F., Garza-López P.M., \& Loera O. (2016). Cellular signaling in cross protection: An alternative to improve mycopesticides. Biological Control, 103: 196-203. https://doi.org/10.1016/j.biocontrol.2016.09.007

Moreau M., Feuilloley M.G.J., Orange N., \& Brisset, J.L. (2005). Lethal effect of the gliding arc discharges on Erwinia spp. Journal of Applied Microbiology, 98: 1039-1046. https://doi.org/10.1111 /j.1365-2672.2004.02535.x

Oliveira, P.M., Mauch, A., Jacob, F., Waters, D.M., \& Arendt, E.K. (2012): Fundamental study on the influence of Fusarium infection on quality and ultrastructure of barley malt. International Journal of Food Microbiology, 156: 32-43. https://doi.org/10.1016/j.ijfoodmicro.2012.02.019
Park B.J., Takatori, K., Sugita-Konishi Y., \& Kim I.H. (2007): Degradation of mycotoxins using microwave inducted argon plasma et atmospheric pressure. Surface \& Coatings Technology, 201: 5733-5737. https:// doi.org/10.1016/j.surfcoat.2006.07.092

Patriarca A., \& Pinto V. F. (2017): Prevalence of mycotoxins in foods and decontamination. Current Opinion in Food Science, 14: 50-60. https://doi.org/10.1016/j.cofs.2017.01.011

Pestka J.J. (2007): Toxicity, mechanisms and animal health risks. Animal Feed Science and Technology, 137: 283-298. http://dx.doi. org/10.1016/j.anifeedsci.2007.06.006

Polišenská I., Jirsa O., \& Matušinský P. (2012): Mycotoxicological quality of barley harvested in the Czech Republic in 2005-2010. Kvasny Prumysl, 58: 109-114. https://doi.org/10.18832/kp2012012

Speijers G.J.A., \& Spejiers M.H.M. (2004): Combined toxic effects of mycotoxins. Toxicology Letters, 152: 91-98. https://doi.org/10.1016/j. toxlet.2004.04.046

Velíšek J., \& Hajšlová J. (2009): Chemie potravin II. OSSIS: 369 Havlíčkův Brod. ISBN: 978-80-86659-16-9 (in Czech).

Wolf-Hall Ch.E.(2007): Mold and mycotoxin problem encountered during malting and brewing, International Journal of Food Microbiology, 119: 89-94. https://doi.org/10.1016/j.ijfoodmicro.2007.07.030 